\title{
The experimental investigation of diesel fuel- biofuel blends at different injection pressures in a DI diesel engine
}

\author{
İlker Örs*, Murat Ciniviz**, Bahar Sayin Kul ${ }^{* *}$ and Ali Kahraman*** \\ * School of Civil Aviation, Selcuk University, Konya, Turkey \\ ** Technology Faculty, Selcuk University, Konya, Turkey \\ *** Faculty of Engineering and Architecture, Necmettin Erbakan University, Konya, Turkey \\ *Corresponding author : ilker.ors@selcuk.edu.tr
}

$\begin{array}{ll}\text { Submitted } & : 26 / 12 / 2019 \\ \text { Revised } & : 24 / 05 / 2021 \\ \text { Accepted } & : 05 / 06 / 2021\end{array}$

\begin{abstract}
In this study, it was aimed to investigate the effects of a diesel-biodiesel blend (B20) and a diesel-biodieselbioethanol blend (BE5) on combustion parameters in addition to engine performance and exhaust emissions compared with diesel fuel. Parameters included in the evaluation was brake specific fuel consumption, brake thermal efficiency, $\mathrm{CO}, \mathrm{CO}_{2}, \mathrm{HC}, \mathrm{NO}_{\mathrm{x}}$, smoke opacity emissions and finally cylinder pressure, heat release rate, ignition delay, some key points of the combustion phases such as start of ignition, start of combustion, CA50 and CA90 and combustion duration. Engine tests were conducted at different injection pressures of $170 \mathrm{bar}, 190 \mathrm{bar}$, which is the original injection pressure, and 220 bar by the engine being loaded by $25,50,75$ and $100 \%$ for the assessment of engine performance and exhaust emissions. For combustion evaluation, the data obtained at $1400 \mathrm{rpm}$, maximum torque-speed, and $2800 \mathrm{rpm}$, maximum power-speed were used, while the injection pressures were set to 170,190 and 220 bar under full load condition. According to test results, the better performance characteristics, exhaust emissions and combustion behaviour of engine were obtained with the use of BE5 at high injection pressure. So, BE5 fuel improved brake specific fuel consumption by about $7 \%$ and brake thermal efficiency by about $6 \%$ compared to B20. In addition, while the emission values of BE5 gave better results than diesel fuel, it reduced the NOx and smoke emissions of B20 by approximately $1.4 \%$ and $6.4 \%$ respectively. Moreover, it has achieved a reduction in smoke emission of up to $45 \%$ compared to diesel fuel.
\end{abstract}

Keywords: Biodiesel; Diesel engine; Engine performance; Exhaust emissions; Ternary fuel blend.

\begin{tabular}{|c|c|c|c|}
\hline \multicolumn{4}{|c|}{ Nomenclature } \\
\hline BSFC & brake specific fuel consumption & DI & direct injection \\
\hline BTDC & before top dead center & D100 & neat diesel fuel \\
\hline $\mathrm{B} 20$ & $20 \%$ biodiesel plus $80 \%$ diesel fuel (volumetric) & $\mathrm{HC}$ & hydrocarbon \\
\hline BE5 & $\begin{array}{l}20 \% \text { biodiesel plus } 5 \% \text { bioethanol plus } 75 \% \text { diesel fuel } \\
\text { (volumetric) }\end{array}$ & HRR & heat release rate \\
\hline BTE & brake thermal efficiency & ID & ignition delay \\
\hline
\end{tabular}




$\begin{array}{llll}\mathrm{CA} & \text { crank angle } & \mathrm{LHV} & \text { lower heating value } \\ \mathrm{CA} 50 & \text { crank angle point for } 50 \% \text { accumulated HRR } & \mathrm{NO}_{\mathrm{x}} & \text { nitrogen oxides } \\ \mathrm{CA} 90 & \text { crank angle point for } 90 \% \text { accumulated HRR } & \mathrm{PM} & \text { particulate matter } \\ \mathrm{CFPP} & \text { cold filter plugging point } & \mathrm{SoC} & \text { start of combustion } \\ \mathrm{CO} & \text { carbon monoxide } & \text { SoI } & \text { start of ignition } \\ \mathrm{CO}_{2} & \text { carbon dioxide } & \text { TDC } & \text { top dead center }\end{array}$

\section{INTRODUCTION}

Diesel engines are the type of internal combustion engines that combines fuel economy and high thermal efficiency- high engine torque but like any man-made device, they have a defect: to cause high exhaust emissions especially $\mathrm{NO}_{\mathrm{x}}$ and $\mathrm{PM}$ emissions. The scarcity of fossil fuels and stringent precautions taken with tightening of emission standards are the driving force of the steps taken. Today, applications are expected to provide high specific power without weakening the driving ability from automotive technology (Pradelle et al., 2019). Therefore, the studies on alternative fuel, that will be a substitute to diesel fuel, are based on the search for fuel to reduce exhaust emissions without concessions of fuel economy and high thermal efficiency. Biodiesel and bioethanol are two alternative distinguished among others. Biodiesel, which is quite similar to diesel fuel, is a form of vegetable oils or animal fats, which is acquired qualification with decreased viscosity, polyunsaturated characteristics and increased volatility by chemical reactions such as transesterification (Mofijur et al., 2016). When the difference between these two quite similar fuels is questioned, the answer is the oxygen content, varying from 10 to 12 depending on which type of oil is be manufactured from, of biodiesel unlike oxygen-free diesel (Noorollahi et al., 2018). This non-toxic and biodegradable fuel decays about four times faster than diesel fuel (Barabás et al., 2010). Oxygen-rich structure of it allows for less release of many exhaust emissions such as $\mathrm{CO}, \mathrm{HC}$ etc. as a result of opening the way for approaching full combustion conditions. Thus, the durability and operational problems, such as being the piston sticked, being clogged the fuel supply line and being lubricant oil thickened, that occur during long-term use of the oil in diesel engines are also overcome (Ilk1lıç et al., 2011; Kannan et al., 2012). Bioethanol, which is a costefficient oxygenate with oxygen content of $34 \%$ by weight, is not suitable for use as pure in diesel engines due to some limitation of it such as low cetane number, low slipperiness, difficulty in evaporation and high ignition temperatures etc. (Hulwan et al., 2011; Yilmaz et al., 2014). Due to the resistance of ethanol to self-ignition, an ignition improver was needed generally such as glow plugs, surface ignition or pilot injections (Kannan et al., 2012). It does not appear to be a detriment to blending it with diesel at low rates (Mofijur et al., 2016; Rakopoulos et al., 2015; Venu et al., 2017). However, the use of particularly high ethanol rates is limited by the difficulty of dissolving bioethanol in diesel fuel and sensitivity of blends to temperature and water content despite the developer effect on cloud point, pour point and cold filter plugging point of blends (Lei et al., 2012; Pradelle et al., 2019). It is preferred to be used as additives to improve the fuel properties of biodiesel such as cetane number, viscosity, cloud point (Noorollahi et al., 2018). $\mathrm{NO}_{\mathrm{x}}$ emissions that biodiesel increases compared to diesel fuel can also be controlled by adding bioethanol. In the triple fuel blend, the polar structure of the biodiesel molecule makes it an effective emulsifier to prevent ethanol from leaving diesel fuel, manifests itself in the form of phase separation, and improves the solubility of ethanol in diesel fuel at a large variety of temperature (HulwanJoshi, 2011; Park et al., 2012; Tse et al., 2015).

It is already studied by many researchers the behavior diesel-biodiesel fuel blends and of triple fuel blends, contains bioethanol additionally, driven diesel engine with regard to especially parameters of engine performance and exhaust emission some of which are presented below. Mofijur et al. (2016) has studied to review the effects of 
biofuels and their blends formed as binary (diesel-biodiesel) and ternary (diesel-biodiesel-bioethanol) on the exhaust emissions. It was reported that exhaust emissions held responsible for a large part of air pollution depends on various parameters such as feedstock, engine operating condition, and biofuel types etc. The most crucial result of the study was that both binary and ternary blends have a general decreasing effect on $\mathrm{CO}, \mathrm{HC}$ and $\mathrm{PM}$ emissions while increasing others $\left(\mathrm{NO}_{\mathrm{x}}\right.$, and $\left.\mathrm{CO}_{2}\right)$. Noorollahi et al. (2018) found in their study based on testing triple fuel blends, which they called diesterol, in various engine speeds that the addition of biodiesel and bioethanol to diesel fuel reduced exhaust emissions. It was detected that ternary blends containing $6 \%$ biodiesel-3\% bioethanol and $2 \%$ biodiesel- $1 \%$ bioethanol played a key role in respect to both engine performance and exhaust emissions. In the study belongs to Yilmaz et al. (2014), it was examined the effect of fuel blends with ethanol ratios of 3\%, 5\%, 15\% and $25 \%$ while the biodiesel and diesel concentrations were kept equal. It has been found that fuels with low ethanol content had an adverse effect with fuels with high ethanol ratio on exhaust emissions of direct injected diesel engine. In another study conducted by Hulwan and Joshi (2011), it was aimed to determine the role of diesel-biodieselbioethanol blends contains bioethanol of $20,30,40 \%$ by volume with respect to engine load. Although not yet the reduction with same proportion in particulate matter, it has been reported that smoke for triple fuel blends has decreased significantly by being effected from ignition delay. Tse et al. (2015) conducted an experimental study based on combustion of diesel engine fuelled by ultra-low sulphur diesel-biodiesel-ethanol blends consist of $15 \%$ biodiesel in each case. Also, they conveyed the trade of relations among $\mathrm{NO}_{\mathrm{x}}$, particulate matters and particle number concentration. It was indicated that in-cylinder pressure and maximum heat release rate increased in reference to diesel and biodiesel. Sastry et al. (2015) investigated the effect of 5-10\% isobutanol and ethanol addition to dieselbiodiesel blends on a direct injection diesel engine operated at different injection pressures $(200,225,250$ and 275 bar). In the study that presented the variation of BTE, BSFC, volumetric efficiency, $\mathrm{CO}, \mathrm{NO}_{\mathrm{x}}$ emissions versus injection pressure, it was realized that thermal efficiency increased with increasing injection pressure for especially ternary fuel blends and ethanol addition led to rise in $\mathrm{CO}$ and $\mathrm{NO}_{\mathrm{x}}$ emissions at high injection pressure. In another study conducted by Prabakaran et al. (2016), the effect of diesel-biodiesel-ethanol blend with and without zinc oxide addition was investigated experimentally in terms of performance, combustion and emission characteristics. It was presented that ternary blend had negative effect on performance parameters it led to decrease in $\mathrm{CO}, \mathrm{HC}, \mathrm{NO}_{\mathrm{x}}$ and smoke emissions in generally. Besides, maximum cylinder pressure and HRR has been affected upwardly from addition biodiesel and bioethanol to diesel fuel. Labeckas et al. (2014) investigated the behaviour of a DI diesel engine fuelled with some diesel-ethanol blends and a diesel-biodiesel-ethanol blend abbreviated as E15B from the viewpoint of SoI, auto ignition delay, combustion analysis, heat release rate, various engine performance parameters and exhaust emissions for different air-fuel ratios and engine speeds. The results of study revealed that $\mathrm{NO}_{\mathrm{x}}$ emissions of E15B were lower for rich air fuel ratios. Paul et al. (2017) have experienced engine operation by using fuel blends, in which the biodiesel ratio was fixed to 50 , ethanol ratio varied from $5 \%$ to $20 \%$. The results of the study, based on exergy, combustion and exhaust emission, put forth that give the blend contains $15 \%$ ethanol had best engine performance and exhaust emissions except $\mathrm{NO}_{\mathrm{x}}$. Another energy-exergy based study, was about usage of diesel, biodiesel and bioethanol fuel blends prepared by injecting 5\% bioethanol to each, was that of Sayin Kul et al. (2016). Fuel blend, contained 3\% biodiesel, was found to be closer to diesel fuel in terms of thermal and exergetic efficiency decreasing with biodiesel content. Çelik et al. (2017) exanimated the characteristics of diesel, biodiesel derived from cottonseed and grapeseed and bioethanol in a diesel engine operated at different engine speeds under full load conditions. With ethanol addition, it was shown decrease in cetane number, viscosity, density and lower heating value of fuel in all engine speeds. Brake torque and brake power affected adversely, when it was observed increase in brake specific fuel consumption, maximum cylinder pressure, and heat release rate and ignition delay. Işık et al. (2016) investigated thoroughly the diesel engine operation with an application of bioethanol reactivity controlled compression ignition at $1500 \mathrm{rpm}$ constant speed. Biodiesel was added to diesel fuel to provide more reactivity to easy start to combustion. Bioethanol was added to form premixed fuel sample as port fuel injection. According to results of their study, both peak cylinder pressure and heat release rate were increased by increase of ethanol ratio in blends. Besides, $\mathrm{CO}$ and $\mathrm{HC}$ emissions in exhaust gas were increased by ethanol ratio. And, it decreased $\mathrm{CO}_{2}$ and $\mathrm{NO}_{\mathrm{x}}$ emissions. 
Biodiesel can blend at every ratio with diesel fuel. But, it was presented that especially blended $20 \%$ biodiesel content improved lubrication properties of fuel, and it decreased exhaust emissions (Aktaş et al., 2009; Van Gerpen et al., 2007). Most of the studies outlined above are about exhaust emissions and performance parameters of diesel engine fuelled with diesel, biodiesel, bioethanol. Therefore, the necessity of comprehensive evaluation in terms of diesel combustion to be containing within itself exhaust emissions and engine performance arises to provide contribution to literature. This study focuses on the comparative effect of BE5 ternary fuel blend with B20 and pure diesel fuel. The operation of test engine loaded by $25,50,75$ and $100 \%$ has been experienced for different injection pressures by using these test fuels.

\section{MATERIALS AND METHODS}

The experimental setup consist of test engine, hydraulic dynamometer, gas analyser and cylinder pressure measurement system shows in Figure1.

The specifications of the test engine are given in Table 1. The engine torque was measured with a hydraulic dynamometer mounted to the test engine with a torque range from 0 to $450 \mathrm{Nm}$ and speed range from 0 to 6500 $\mathrm{rev} / \mathrm{min}$. The torque has been read with the help of a load cell branded CAS-SBA 200L. A fuel measurement unit consisting of a tank and a load cell and orifice plate placed on the intake manifold line were used for measure fuel consumption and air consumption respectively. K-type thermocouples have been placed at appropriate surfaces to measure air temperature, inlet and outlet temperatures of the cooling water and exhaust temperature. A gas analyser capable of measuring $\mathrm{CO}, \mathrm{CO}_{2}, \mathrm{HC}, \mathrm{NO}_{\mathrm{x}}$ and smoke opacity was used to determine the release of each. The accuracy of measuring instruments used during engine tests is outlined in Table 2.

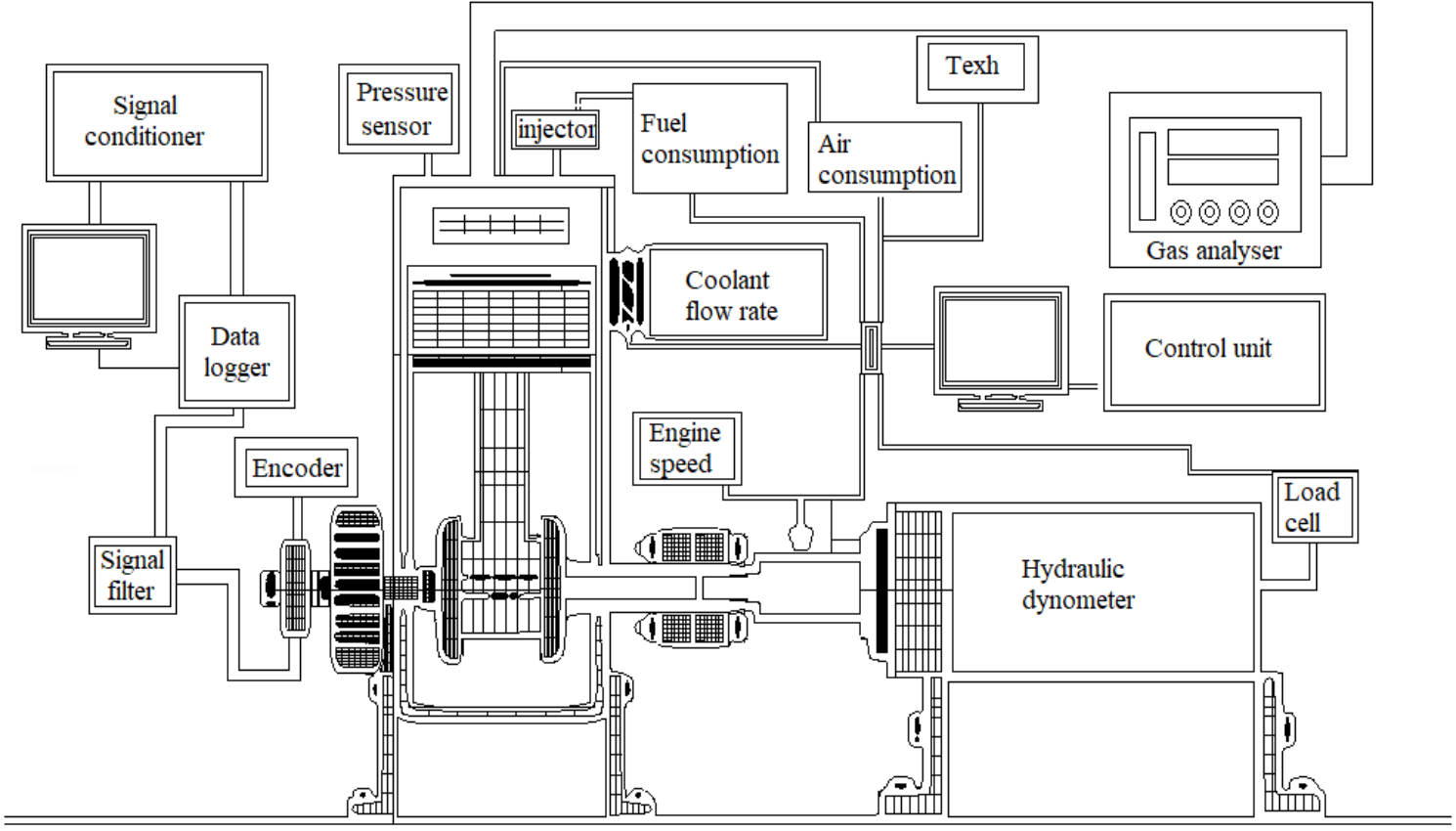

Figure1. Experimental setup 
Table 1. The specification of test engine

\begin{tabular}{|c|c|}
\hline Engine type & Direct injection diesel engine \\
\hline Cylinder number & 1 \\
\hline Bore x Stroke & $85 \mathrm{~mm}$ x 90 mm \\
\hline Compression ratio & $17.5: 1$ \\
\hline Cooling type & Water cooling \\
\hline Cylinder volume & $500 \mathrm{cc}$ \\
\hline Maximum engine torque & $36 \mathrm{Nm} @ 1400 \mathrm{rpm}$ \\
\hline Maximum engine power & $9 \mathrm{~kW} @ 2800 \mathrm{rpm}$ \\
\hline Injector pressure & $190 \mathrm{bar}$ \\
\hline
\end{tabular}

Table 2 The accuracies of test equipment

\begin{tabular}{|c|c|}
\hline Measurements Instruments & Accuracies \\
\hline Exhaust Gas Analyser & \pm 0.1 \\
\hline $\mathrm{CO}_{2}, \% \mathrm{v} / \mathrm{v}$ & \pm 0.01 \\
\hline $\mathrm{CO}, \% \mathrm{v} / \mathrm{v}$ & \pm 1 \\
\hline $\mathrm{HC}, \mathrm{ppm}$ & \pm 1 \\
\hline $\mathrm{NO}_{\mathrm{x}}, \mathrm{ppm}$ & \pm 0.01 \\
\hline Smoke opacity, $1 / \mathrm{m}$ & 1 \\
\hline Thermometer $\left({ }^{\circ} \mathrm{C}\right)$ & 0.01 \\
\hline Load Cell $(\mathrm{g} / \mathrm{sec})$ & 0.0001 \\
\hline Hydraulic dynamometer $(\mathrm{Nm})$ & 1 \\
\hline Engine Speed Sensor $(\mathrm{rpm})$ & \\
\hline
\end{tabular}


Diesel fuel has been evaluated as the reference fuel throughout this study to explain its difference from the others. To be used in the engine tests, biodiesel was produced from safflower oil by transesterification from safflower seed oil using bioethanol produced from sugar beet as a monohydric alcohol and sodium hydroxide as catalyst for the transesterification. Then fuel blends were formed by mixing diesel-biodiesel and bioethanol at different proportions volumetrically. Diesel, biodiesel and bioethanol contents of test fuels as volume percentage and fuel properties of each are shown in the Table 3. While D100 represents the pure diesel fuel, the letters of B and E is abbreviation of biodiesel and bioethanol respectively.

Table 3. Contents and some properties of test fuels

\begin{tabular}{|c|c|c|c|}
\hline \multirow{2}{*}{ Content/Properties } & \multicolumn{3}{|c|}{ Test fuels } \\
\cline { 2 - 4 } & D100 & B20 & BE5 \\
\hline Diesel Fuel, \% & 100 & 80 & 75 \\
\hline Biodiesel, \% & - & 20 & - \\
\hline Bioethanol, \% & 75 & 20 & 5 \\
\hline Density, kg/m ${ }^{3}$ at $15^{\circ} \mathrm{C}$ & 834.5 & 844.4 & 841.7 \\
\hline Viscosity, mm ${ }^{2} / \mathrm{s}$ at $40^{\circ} \mathrm{C}$ & 2.794 & 3.02 & 2.917 \\
\hline Cetane number & 55.2 & 55.5 & 54.1 \\
\hline Low heating value, $\mathrm{MJ} / \mathrm{kg}$ & 43.145 & 42.038 & 41.347 \\
\hline Flash Point, ${ }^{\circ} \mathrm{C}$ & 68.5 & 86.5 & $<25$ \\
\hline Cold Filter Plugging Point, ${ }^{\circ} \mathrm{C}$ & -14 & -11 & -13 \\
\hline Water content, ppm & 70 & 135 & 130 \\
\hline
\end{tabular}

The experiments have been carried out after the engine was run to be reached to the operating temperature of it. Performance and emission tests were performed at different injection pressures (170, 190 and 220 bar) for four different engine loads $(25,50,75$ and 100\%). Combustion analysis tests were carried out at $1400 \mathrm{rpm}$, maximum torque-speed, and $2800 \mathrm{rpm}$, maximum power-speed, while the injection pressures were set to 170, 190 and 220 bar under full load condition. Engine tests were conducted between $170-220$ bar injection pressures with 5 bar intervals. Engine performance values began to rapidly decrease at under 170 bar and over 220 bar injection pressures. Therefore, experiment results obtained at these injection pressures have been presented. Test engine were fueled with all test fuels under the conditions of each experiment. 


\section{RESULTS AND DISCUSSION}

\section{Performance Characteristics}

As results of engine performance, BSFC and BTE values have been presented under four different engine load at 170, 190 and 220 bar injection pressure.

\section{Brake Specific Fuel Consumption}

BSFC symbolizes the mass flow rate of fuel used by the engine to obtain per unit of brake power. Figure 2 shows the variation of brake specific fuel consumption of test fuels with regard to engine loads and injection pressures. BSFC tends to fall until load of $75 \%$, after it has taken the minimum value at the load of $75 \%$, it starts to increase up to full load condition. When there is no stability at low loads in BSFC due to the incomplete combustion, ranking of BSFC from higher to lower is obtained at engine operated with B20, BE5 and diesel for all injection pressure values at engine load of $75 \%$.

When based on the full load condition, it is noticed that BE5 has the highest BSFC value among others in the same injection pressure conditions. Even though BSFC is affected by the high density of biodiesel and bioethanol, lower heating value (LHV) is appeared as more dominant feature here. BSFC is more related to LHV such that the addition of biodiesel with low LHV (2.57\% lesser) to the fuel and the addition of bioethanol with the lower LHV than that of the biodiesel (1.64\% lesser) provide a gradual increase in BSFC compared to diesel fuel at full load. Some studies confirming the increase in BSFC with biodiesel and bioethanol addition is in existence i.e.: (Can et al., 2016; Çelik et al., 2017). One the other hand, higher density and viscosity of biodiesel caused poor atomization (Yildizhan et al., 2017). Therefore, BSFC values increase by about $12.46 \%$ according to diesel fuel. Although bioethanol addition increases BSFC by $6.33 \%$ compare to diesel fuel, it decreases BSFC by $5.45 \%$ according to B20 averagely (Jamrozik et al., 2017) because it provides better atomization by reducing density and viscosity of test fuel. Considering the effect of the pressure it is observed that increase in injection pressure has a decreasing effect on BSFC for all test fuels at each engine loads. While the increment of injection pressure is improved BSFC values by $7 \%$ for B20 due to lower droplet diameter, that of BE5 are approximately by $6.7 \%$ lower than diesel fuel at partial engine loads averagely (Shehata et al., 2015) (Du et al., 2018).

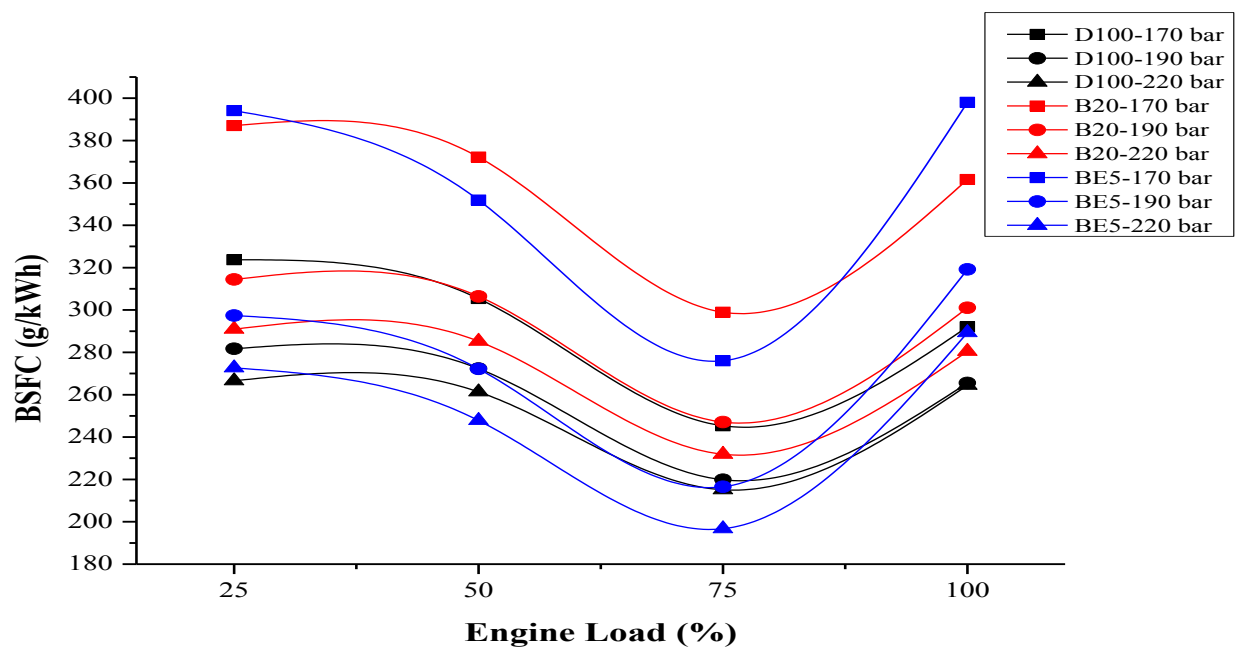

Figure 2. Variation of BSFC at different engine loads and injection pressures 


\section{Brake Thermal Efficiency}

BTE is an expression of the conversion of fuel energy of fuel, which the engine is operated with, into mechanical energy per engine cycle. The variation of BTE at different engine loads and injection pressures is shown in Figure 3. It is found that BTE values corresponding to very high and very low loads are less. Especially at low loads, the values of BTE close to each other make it difficult to comment on the operation of the engine. An explicit increase is observed in BTE up to reach a maximum point, which is at engine load of $75 \%$ and then begins to decrease. At $75 \%$ load condition, ethanol added fuel blend has a higher brake thermal efficiency at 190 and 220 bar. At full load condition, the sequence from highest to lowest in point of BTE is diesel, B20, BE5 respectively. It is due to the energy density of fuel blends in comparison with diesel fuel, for instance biodiesel has 33\% lower energy density than diesel (Li et al., 2005). Engine power which is reduced as a result of worse spraying characteristics due to high densityviscosity of biodiesel also manifests itself as a reduction (by about $8.75 \%$ compare to D100 averagely) in brake thermal efficiency. However, BE5 has higher BTE values by 5\% at especially mid-engine loads averagely. For all engine loads, and test fuels, each variation with the direction of increase in injection pressure resulted in an increase in BTE. This is associated with the reduction in the diameter of the fuel droplets depending on rise in injection pressure. Thus, an increase with BE5 fuel is obtained by average $6 \%$ and $11.4 \%$ respectively according to diesel and B20. It has also been confirmed by different studies that fuel injection pressure has effected positively engine performance of diesel engines used biofuels as in (Sastry et al., 2015).

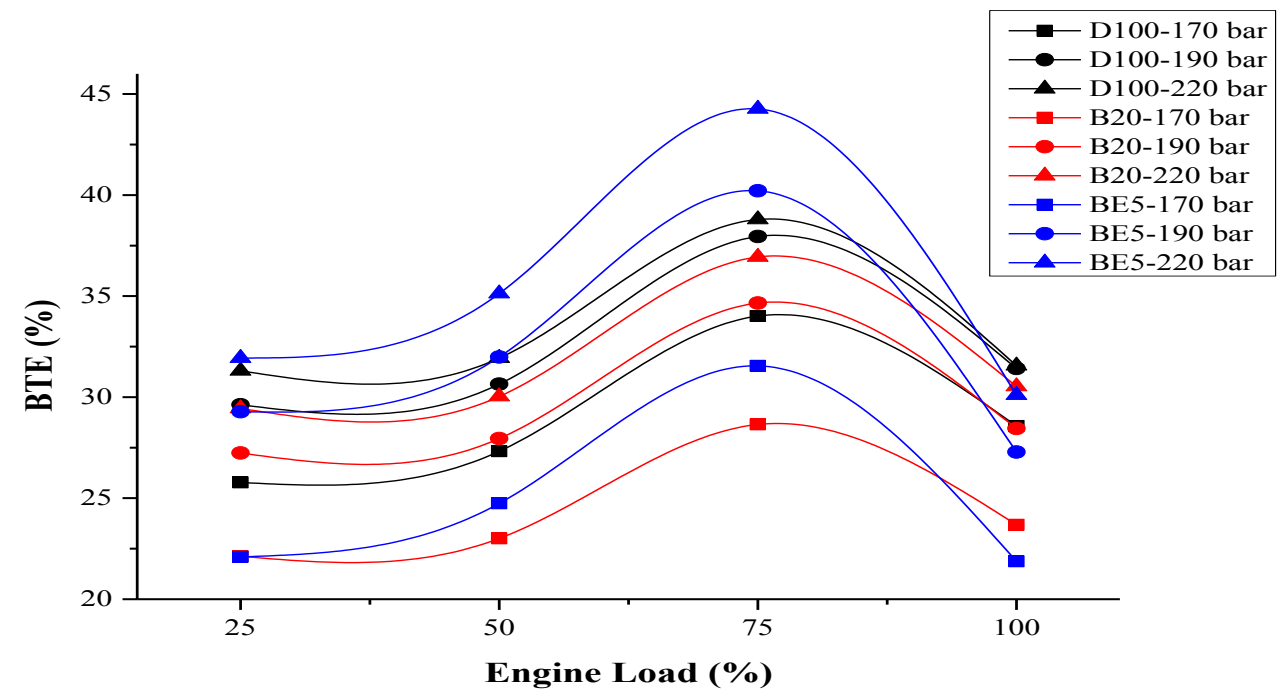

Figure 3. Variation of BTE at different engine loads and injection pressures

\section{COMBUSTION ANALYSES}

In this section, assessments in terms of combustion analysis are based on cylinder pressure, heat release rate, the phases of combustion by touch on SoI, SoC, CA50, CA90 with and combustion duration.

\section{Cylinder Pressures and Heat Release Rate}

Variation of cylinder pressure and heat release rate versus crank angle in the case of the test engine run at 1400 rpm under the full load condition is shown both Figure 4 (a) for the original injection pressure of 190 bar and Figure 4 (b) for others. Cylinder pressure is a representation to what extent the combustion is quality in the cylinder (Paul et 
al., 2017). Maximum cylinder pressure values obtained at 220 bar injection pressure for all test fuels. Its curve has reached its maximum value of 94.52 bar at $8^{\circ} \mathrm{CA}$ for diesel. Other maximum points are 94.31 bar and 94.83 bar at $8^{\circ} \mathrm{CA}$ for B20 and BE5 respectively. Addition of both oxygen-containing fuels result in higher in-cylinder pressure compared to that of diesel but the difference between B20 and BE5 is more noticeable than that of B20 and diesel. The main reason for that is the worse atomization and incomplete combustion caused by the injection of fuel which has aggrieved by the addition of biodiesel (Paul et al., 2017). The difference enhances by bioethanol addition due to the effect of low viscosity. It can be seen from the Figure 4, the maximum heat release rate is obtained for BE5, B20 is on the second rank and diesel is the last one at all engine loads. The reason why the highest heat release rate is obtained for BE5 is that longer ignition delay, with better volatility, higher latent heat of vaporization and lower viscosity characteristics of bioethanol lead to cumulate the fuel not yet burned, which will burn very suddenly in the next phase (Tse et al., 2015). The combustion of bioethanol results in rapid heat release and low maximum pressure which is delayed until the expansion stroke (Pradelle et al., 2019). When ethanol concentration was higher, the ignition delay increased due to the combined effect of several physicochemical properties, namely the higher latent heat of vaporization, the specific heat at constant pressure and the lower cetane number of ethanol. However, when the combustion occurs, the heat is released faster. As a consequence, the maximum pressure is lower and observes lately in the expansion stroke.

Figure 5 demonstrates the variation of both cylinder pressures and heat release rate at $2800 \mathrm{rpm}$ versus crank angle. The difference between the two curve is that the first one is recorded when the engine run at 190 bar, the latter is recorded at 170 and 220 bar. In Figure, the combustion behavior of test fuels can be clearly seen with especially phases of premixed combustion and controlled combustion. When evaluated together with the curve of cylinder pressure and heat release rate at $1400 \mathrm{rpm}$, it is determined that combustion started later (namely at a closer crank angle to TDC) at $2800 \mathrm{rpm}$ at the same injection pressures and test fuels. Besides, the curve of heat release rate tends to shift from TDC to the right such that it becomes more pronounced for ethanol-containing fuel blend. The dense and viscous structure of ethanol paves the way for combustion to be faster and with more heat release rate.

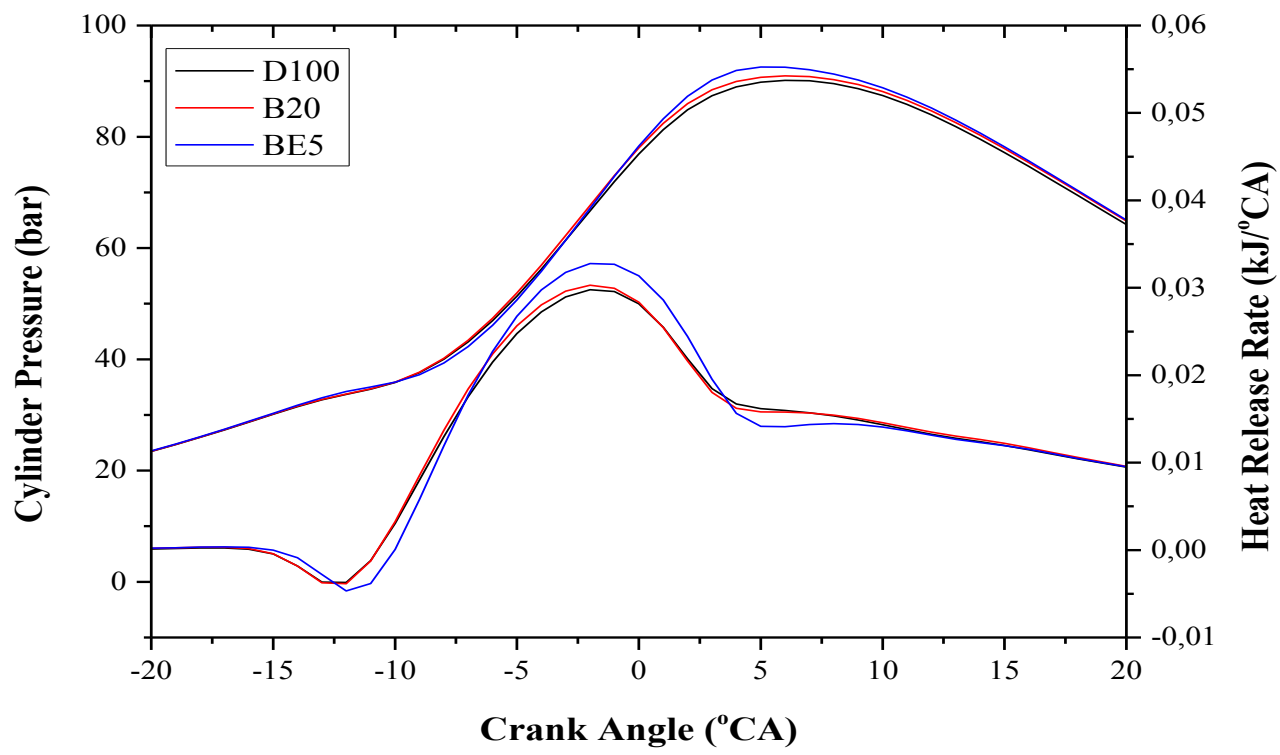

(a) 


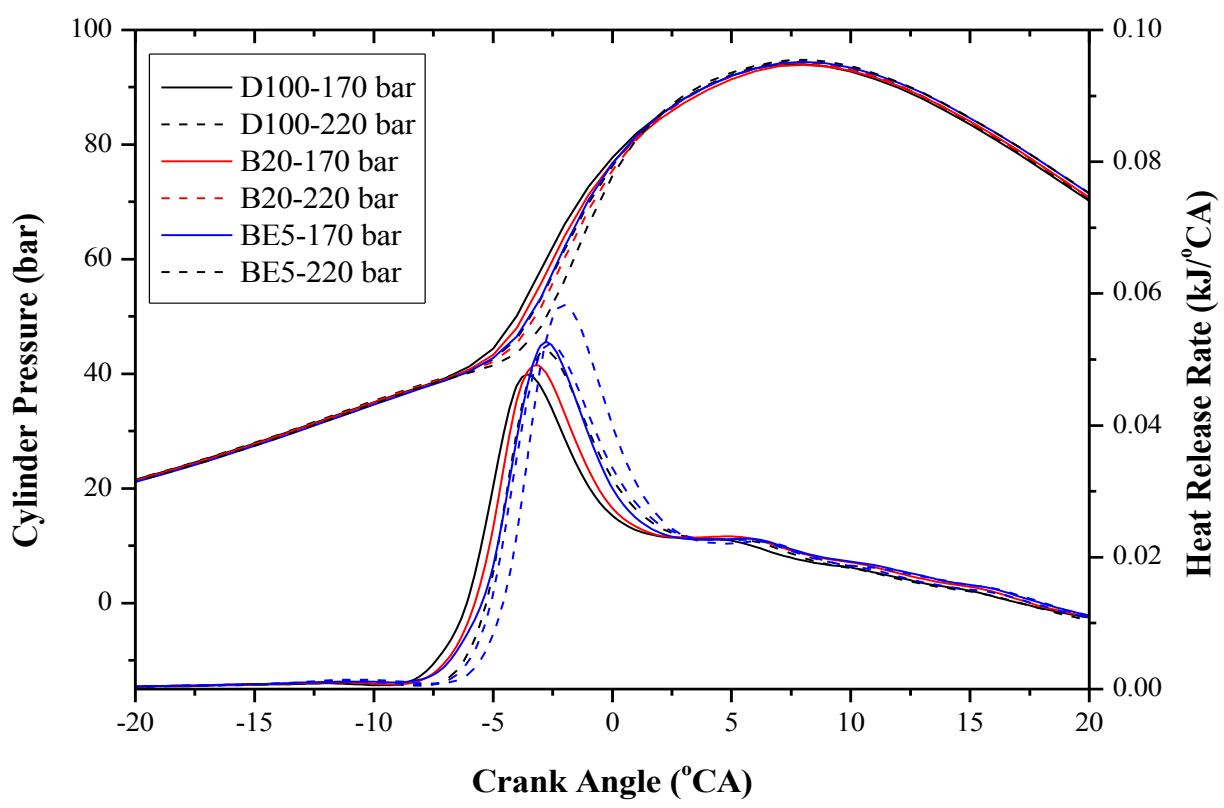

(b)

Figure 4. Variation of cylinder pressure and heat release rate and $1400 \mathrm{rpm}$ versus crank angle at 190 bar (a) and 170, 220 bar (b)

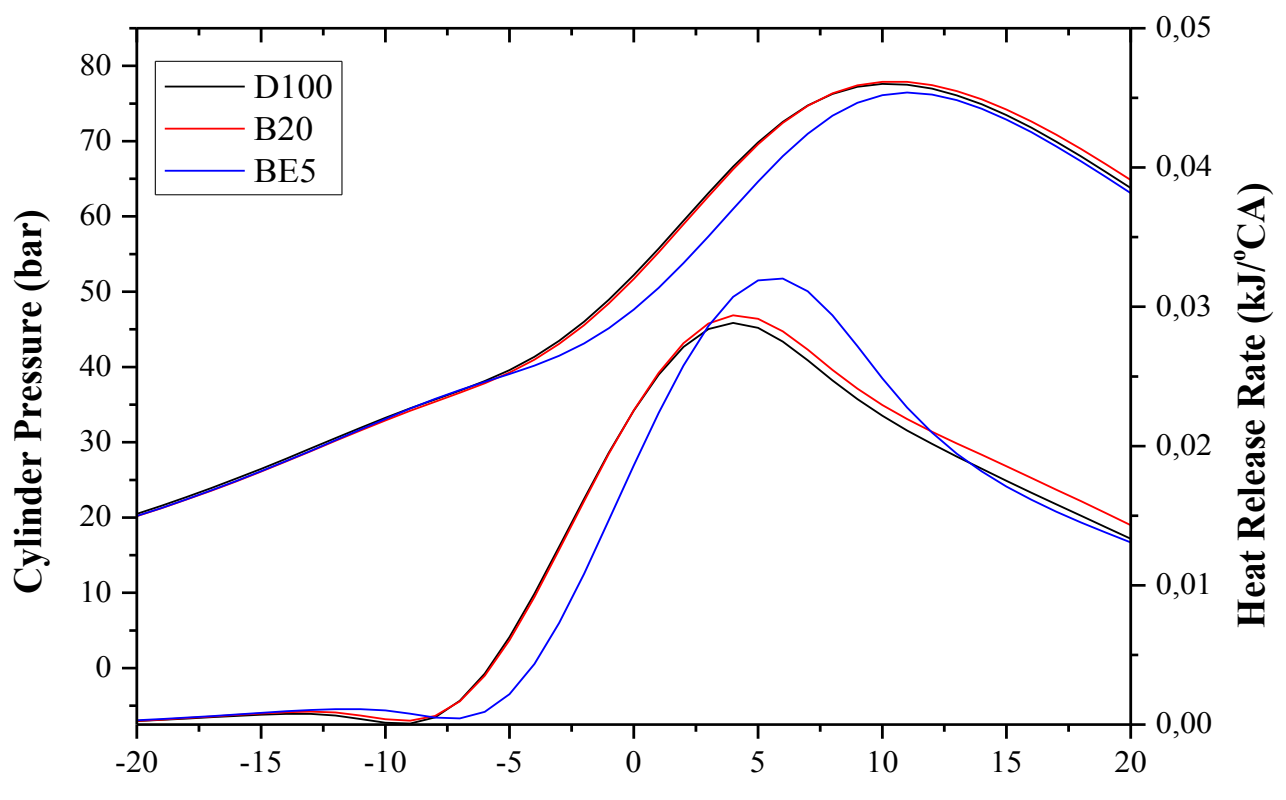

Crank Angle ( $\left.{ }^{\circ} \mathrm{CA}\right)$

(a) 


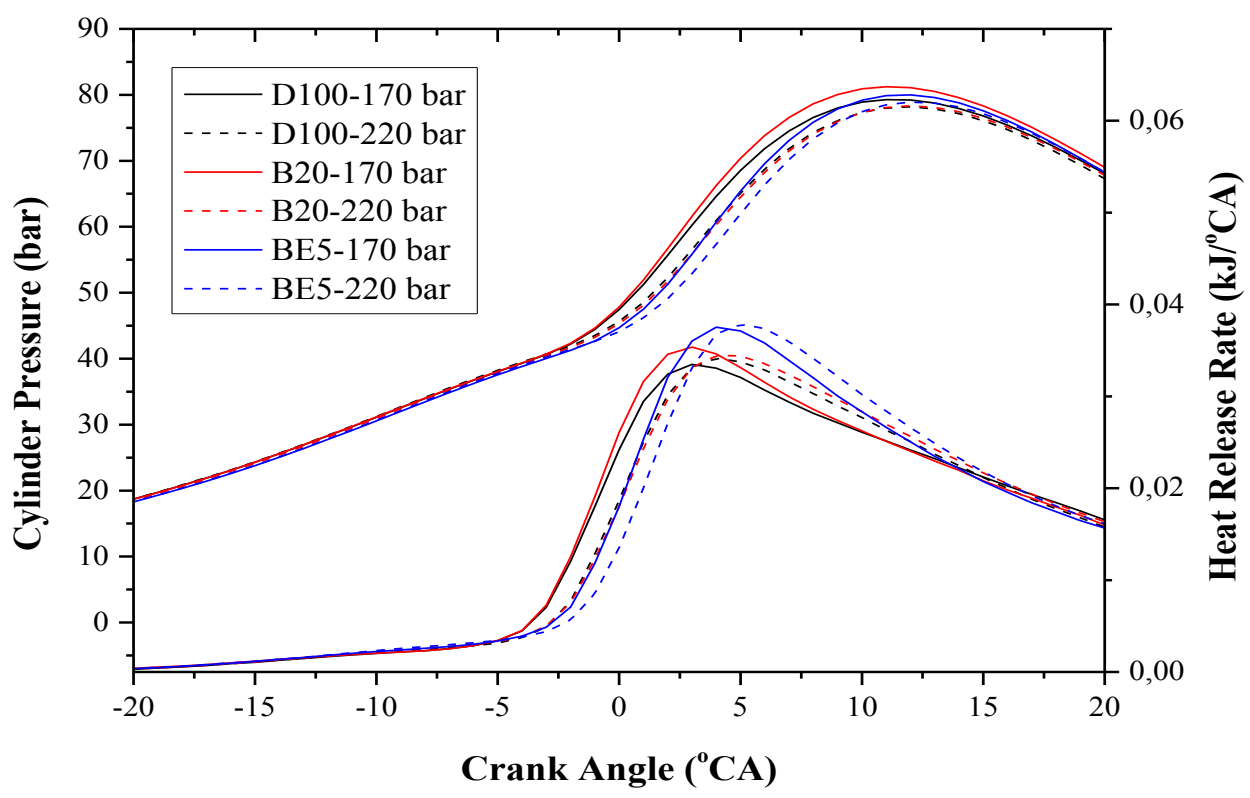

(b)

Figure 5. Variation of cylinder pressure and heat release rate and $2800 \mathrm{rpm}$ versus crank angle at 190 bar (a) and 170, 220 bar (b)

\section{SoI, SoC, CA50, and CA90}

In Figure 6, the variation of SoI, SoC, CA50 and CA90 are shown for all test fuels. Since combustion occurs in the form of different combustion phases, it is useful to examine each phase separately. The SoI and SoC expressions expressed in this figure show the ignition start and the start of the combustion, respectively. Ignition delay, observed as a rapid increase in pressure or inception of heat release, described as time interval from start of fuel injection to the start of combustion (Lakshminarayanan et al., 2010). Late start of combustion results in long ignition delay as expected. As can be seen in Figure 6, at all injection pressures, diesel and BE5 start to combustion later than the crank angle at which the B20 starts, so ignition delay has longer time. B20 pave the way to advance phases of premixed combustion by means of short ignition delay. It is stated that variation of ignition delay is caused by oxygen content, lower heat capacity and higher cetane number of biodiesel (Can et al., 2016). When evaluated in comparison with the original pressure of $190 \mathrm{bar}$, an increase in ignition pressure is prolonged the duration of the ignition delay while the decrease in injecting pressure has the opposite effect except diesel fuel. Bioethanol addition has an increasing effect at all injection pressures on ignition delay, which is clearly visible at 170 bar and 190 bar. The bioethanol causes to lower cetane number and higher latent heat of evaporation, which is directly related to the decrease in cylinder temperature, of the ternary fuel blends so ignition delay increases by adding ethanol (Tse et al., 2015). It has been made similar point that start of combustion for ethanol-containing blend is delayed compared to diesel fuel by Hulwan and Joshi (2011). The prolonged ignition delay by the addition of bioethanol has been associated with the low cetane number of bioethanol by Park et al. (2012) by being based on different studies. CA50 and CA90 represent the crank angle where combustion energy of 50 and $90 \%$ has been released respectively. Also, C50 and C90 are assumed to coincide with the phase of premixed combustion and end of the combustion. If a curve that passes through the marked points has been created, slope of curves is found to be quite similar. This means is that the crank angle at which C50 and C90 obtained are onward for B20 and diesel fuel in almost all pressure. The reason for this is that the 
bioethanol in the fuel increases the burning rate as shown in Figure 5, causing the CA50 and CA90 points to be obtained earlier than other fuels. Because bioethanol burns earlier due to its oxygen content and high latent heat of vaporization. In order to use the energy obtained from the fuel more efficiently, the CA50 value is required to be close to TDC. Similarly, obtaining the CA90 value at lower angles will increase the efficiency of the thermal efficiency as it represents the end of the combustion in general. When the obtained results are examined, it is seen that CA50 and CA90 values of BE5 fuel are obtained at more suitable angles compared to other fuels.

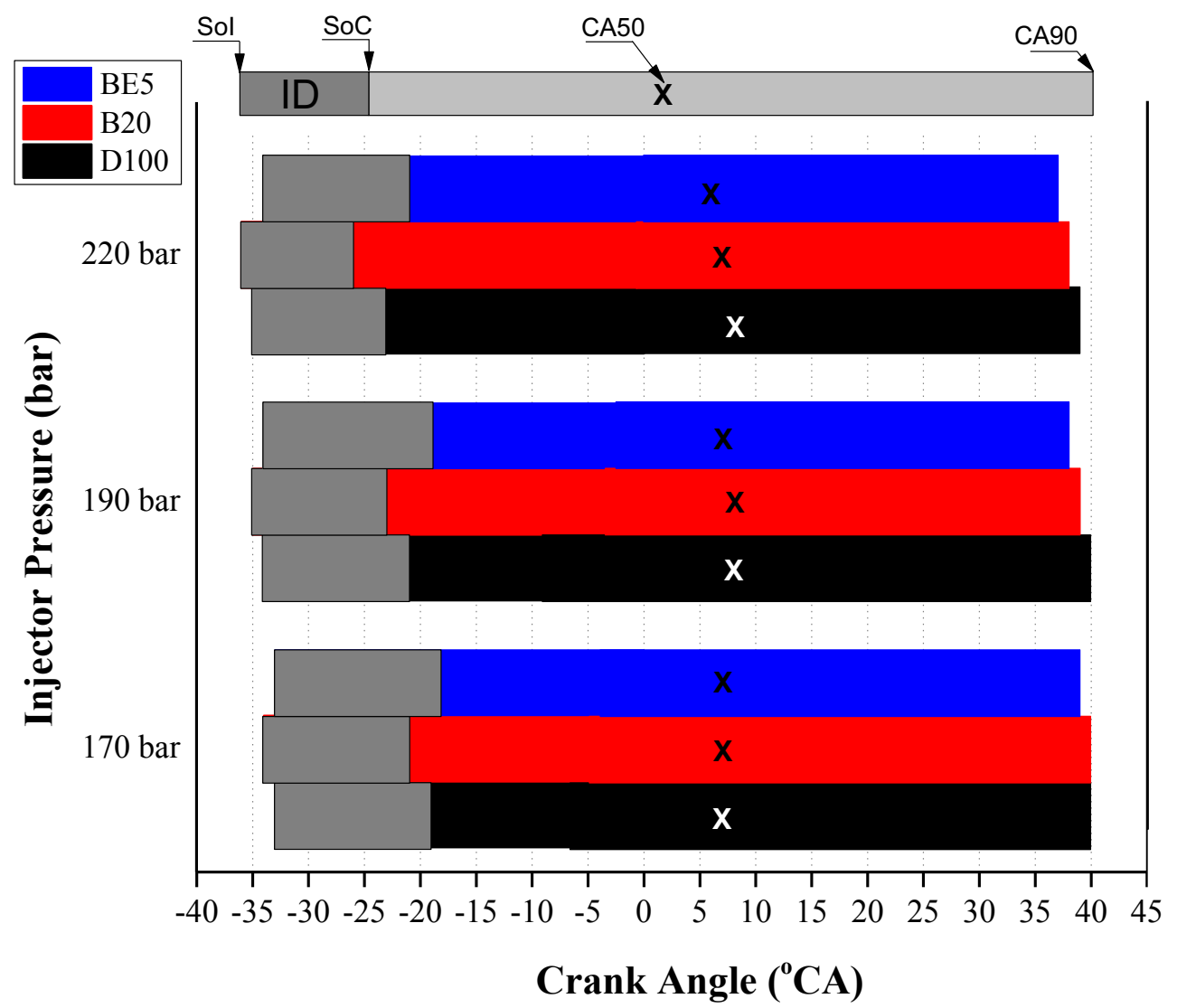

Figure 6. Variation of SoI, SoC, CA50, and CA90 for all injection pressures versus crank angle

\section{Combustion Duration}

Figure 7 indicates the variation of combustion duration, covering the period between the beginning and end of the combustion, versus injection pressures for all test fuels under full load condition. At both 170 and 220 bar injection pressures, diesel has taken longer time to combustion. When the engine is operated with B20 and BE5, this period significantly reduced. Although the ignition delay of the BE5 is longer than that of the others, the combustion of it takes short time. It indicates that amount of fuel burned in the phases of premixed combustion higher when using BE20. At 190 bar engine load, the combustion duration has not been affected much more by the addition of biodiesel to fuel such that, the combustion duration remains stable with biodiesel addition. 


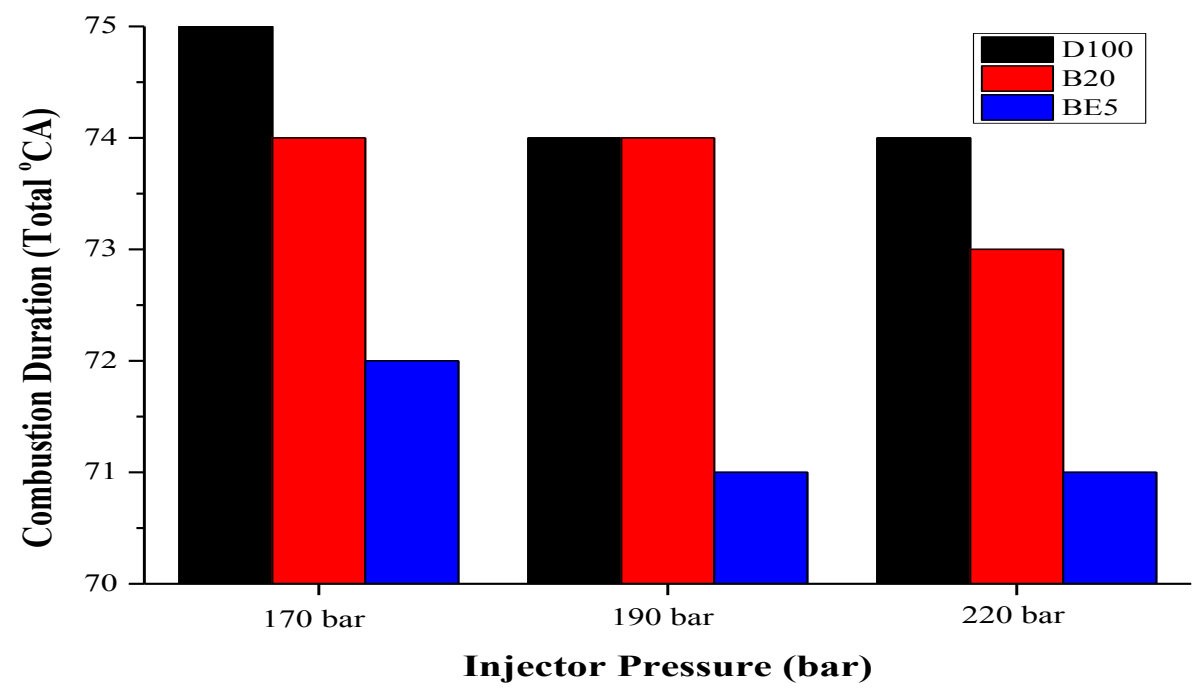

Figure 7. Variation of combustion duration for all injection pressures versus crank angle

\section{EXHAUST GAS TEMPERATURE}

Measurement of exhaust gas temperatures allows us to explain what causes the variation of exhaust emissions, and to be informed on how combustion occurs by associating with combustion temperatures. Figure 8 presented the variation of exhaust gas temperature according to engine operated with test fuels at different engine loads and injection pressures. In all engine loads except diesel fuel at full load conditions, as can be seen, B20 has higher exhaust gas temperatures than that of diesel fuel even though there is a minor difference between BE5. With the addition of ethanol to the blend, a diminishment, which is explained by the high heat of vaporization of ethanol observed for all engine load (PrabakaranUdhoji, 2016). Although the B20 fuel has a linear increase related to rise in injection pressure, it is difficult to say the same for other fuels, especially at high engine loads. Exhaust gas temperature of BE5 decreased with increase of injection pressure due to its higher combustion speed.

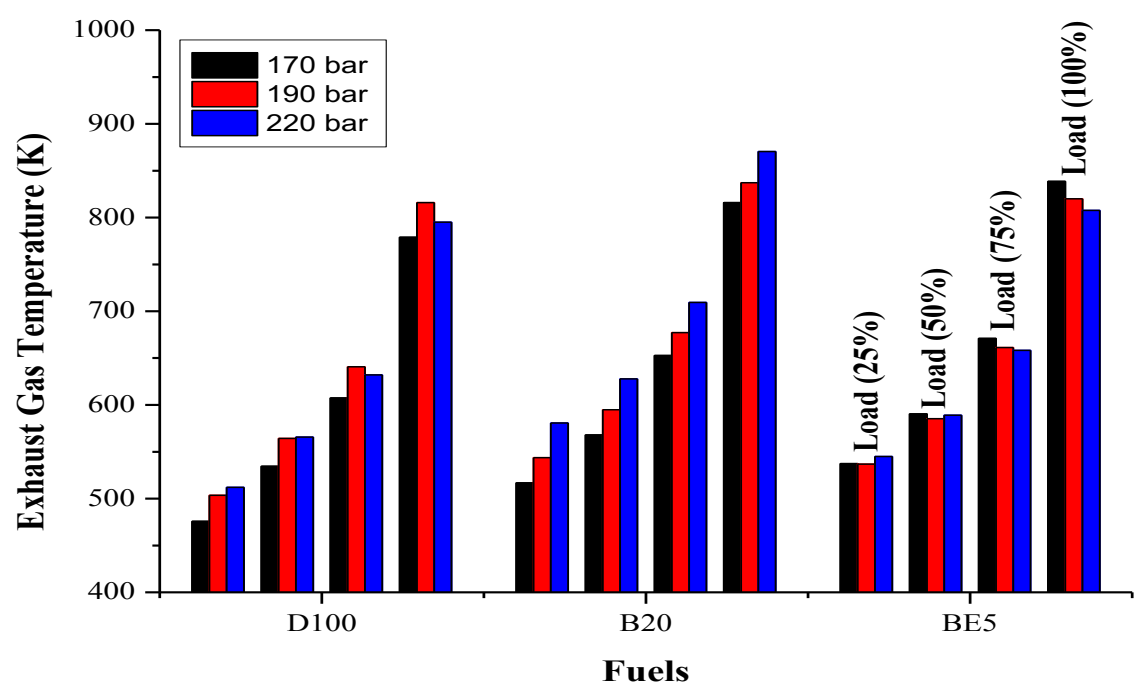

Figure 8. Variation of exhaust gas temperature at different engine loads and injection pressures 


\section{EXHAUST EMISSIONS}

\section{Carbon Monoxide Emissions}

The formation of $\mathrm{CO}$ emissions is a sign that oxygen is insufficient to generate $\mathrm{CO}_{2}$ during combustion. When the same two test conditions are compared, the increase in $\mathrm{CO}_{2}$ emissions from one state to another means that the complete combustion is approached and therefore the $\mathrm{CO}$ emission decrease. As engine load increases, $\mathrm{CO}$ emissions also increase at the same rate, so that it is highest at maximum load due to the continued oxidation even in the exhaust stroke. As it can be seen in Figure 9, represents the curve of CO emissions versus engine load for all test fuel, there is a tendency as diesel fuel to be the highest, B20 to be the medium and BE5 to be the lowest in almost all engine load conditions. $\mathrm{CO}$ emission values of B20 and BE5 fuels are lower by average $10.2 \%$ and $41.6 \%$ respectively than that of diesel. A decrease in $\mathrm{CO}$ emissions is observed as injection pressure increases no matter what load and with which fuel the engine operates. Oxygen content of both biodiesel and bioethanol stimulate the necessary conditions to cleaner combustion which results in a reduction in CO emissions (Mofijur et al., 2016). The improvement in CO emissions is observed by $6.5 \%$ for B20 and by $5 \%$ for BE5 with the rise of injection pressure. Decrease in CO emissions at high injection pressure can be explained by improved spray quality of B20 and BE5 fuels have high density, with increasing injection pressure.

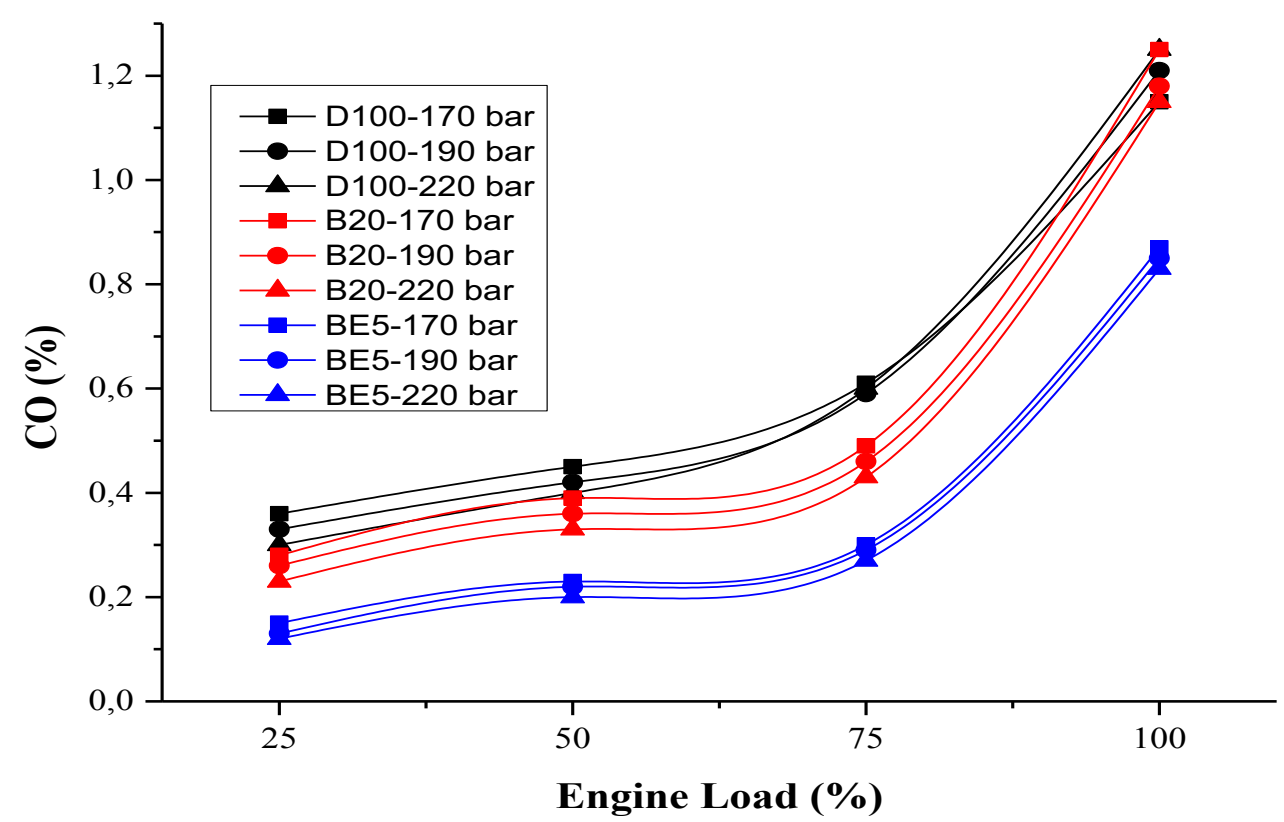

Figure 9. Carbon monoxide emissions at various engine loads and injection pressures

\section{Carbon Dioxide Emissions}

Figure 10 illustrate the variation of $\mathrm{CO}_{2}$ emissions for all test fuels versus engine load. The use of $\mathrm{B} 20$ in the test engine leads to release more $\mathrm{CO}_{2}$ (by $6.4 \%$ and by $8.8 \%$ respectively compared to diesel and $\mathrm{BE} 5$ ) emissions compared to others arising from enhanced combustion quality. Bioethanol, although not comparable with biodiesel, has also provided an increase in its own right. In (Noorollahi et al., 2018), Higher $\mathrm{CO}_{2}$ emissions compared to diesel 
fuel is associated with higher cetane number of biofuels. Any moves up or down from the original pressure value of 190 bar has the effect of reducing emissions for all test blends.

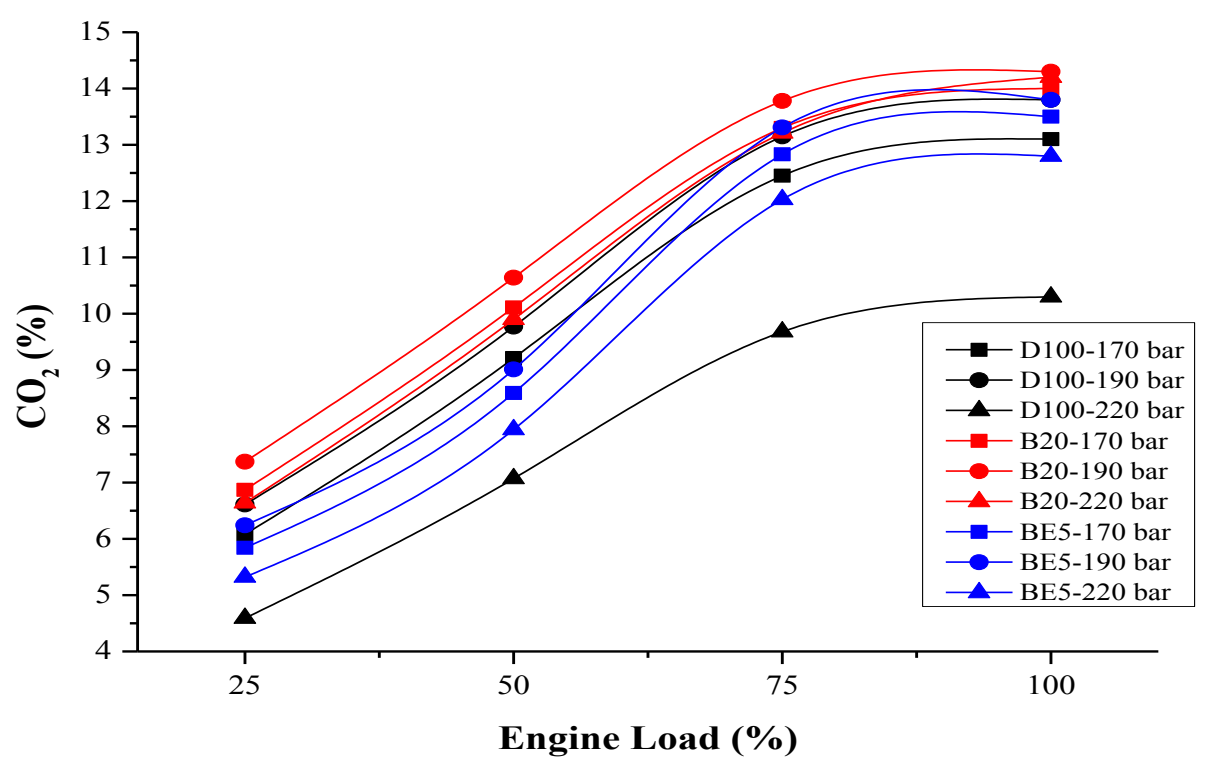

Figure 10. Carbon dioxide emissions at various engine loads and injection pressures

\section{Hydro Carbon Emissions}

The variation of $\mathrm{HC}$ emissions at various engine loads and injection pressures for diesel, B20 and BE5 is shown in Figure 11. As in $\mathrm{CO}$ emissions, $\mathrm{HC}$ emissions are also the result of incomplete combustion, or more precisely fuel that is not involved in the combustion. Biodiesel contributes to diesel fuel in this sense so HC emissions decrease in the case of engine operated with B20 because of advance premixed combustion. Similar relationship between HC emissions of diesel-biodiesel blend and engine load has been detected in (Barabás et al., 2010). HC emissions of B20 and BE5 have never reached up the value as high as that of the diesel fuel. Biodiesel is decreased HC emissions by $27 \%$ due to the oxygen content of it (Can, 2014). Although bioethanol addition in B20 fuel is increased HC emission by average $8.2 \%$ compared to $\mathrm{B} 20$, it has lower $\mathrm{HC}$ emission by approximately $21 \%$ according to diesel fuel. It is observed reduction (4.1\% according to 190 bar) in $\mathrm{HC}$ emissions due to better atomization of B20 with increased injection pressure. Quickly extinction of flame owing to high combustion speed of BE5 at high injection pressure increased $\mathrm{HC}$ emissions by $8.3 \%$ compared to engine load of 190 bar. 


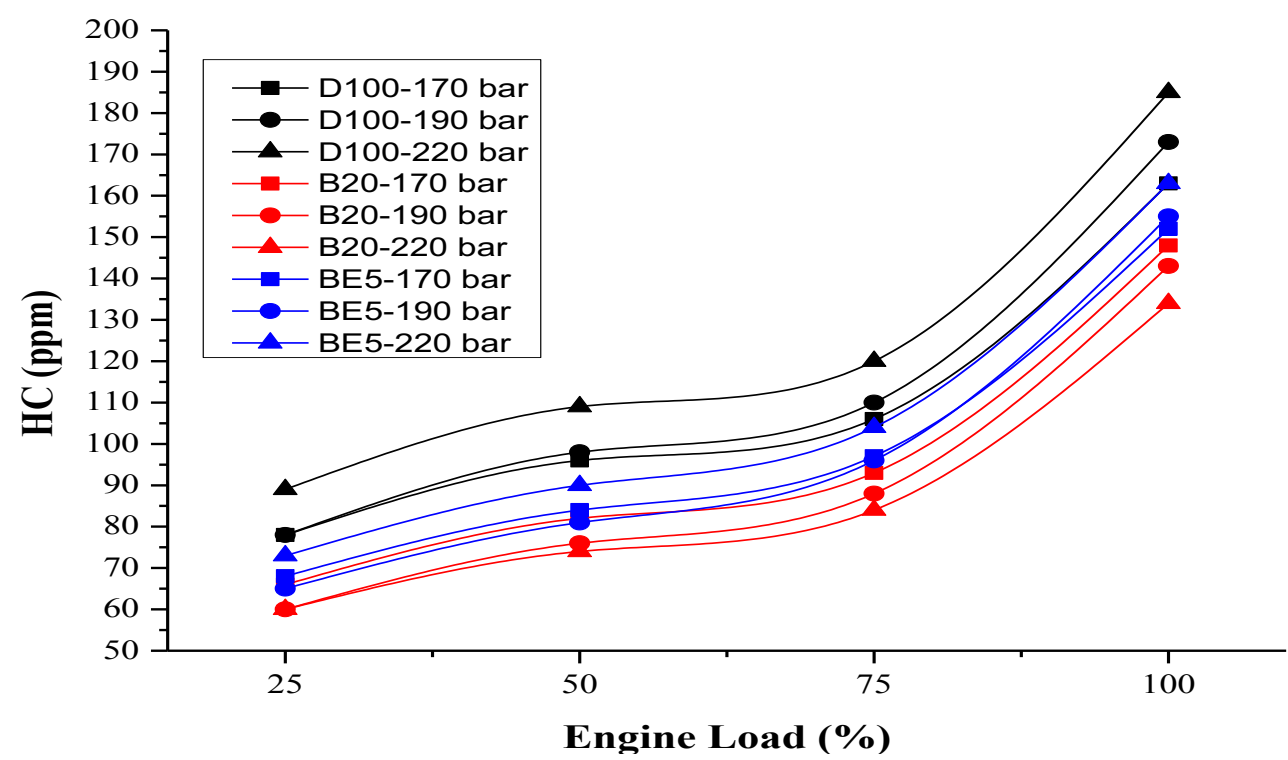

Figure 11. HC emissions at various engine loads and injection pressures

\section{NO $\mathrm{x}_{\mathrm{x}}$ Emissions}

Figure 12 emerges the $\mathrm{NO}_{\mathrm{x}}$ emissions at various engine loads and injection pressures. $\mathrm{NO}_{\mathrm{x}}$ emissions are affected by many different parameters, some of which are classified as favourable such as lower cetane number of alcohol, lower ratio of exhaust gas recirculation, while some are classified as unfavourable such as higher heat of evaporation of alcohol and lower C:H ratio etc. (Pradelle et al., 2019). Besides, there are two features that are quite dominant in the formation mechanism of $\mathrm{NO}_{\mathrm{x}}$ emissions: high temperature in the cylinder during combustion and oxygen required for $\mathrm{NO}_{\mathrm{x}}$ formation reactions. Oxygen rich structure is combined with in-cylinder temperatures, thought to be high due to high exhaust gas temperature, it is expected that $\mathrm{NO}_{\mathrm{x}}$ emissions of $\mathrm{B} 20$ will be higher than diesel fuel. It is observed that although biodiesel increases $\mathrm{NO}_{\mathrm{x}}$ emissions by average $12.36 \%$ compared to diesel fuel, it was decreased $6.5 \%$ with bioethanol addition according to B20. BE5 has more imperceptible effect on $\mathrm{NO}_{\mathrm{x}}$ emissions unlike B20 such that it is under the influence of increase in injection pressure at the same rate with diesel fuel. Rise in injection pressure causes an increment in exhaust gas temperature of $\mathrm{B} 20$ fuel. Therefore, $\mathrm{NO}_{\mathrm{x}}$ emissions increase by average $17.4 \%$ for B20. But, $\mathrm{NO}_{\mathrm{x}}$ emission values are decreased by approximately $1.4 \%$ with $\mathrm{BE} 5$ which it has lower exhaust gas temperature. The results are very similar with studies of Emiroğlu et al. (2018) and Valente et al. (2012). 


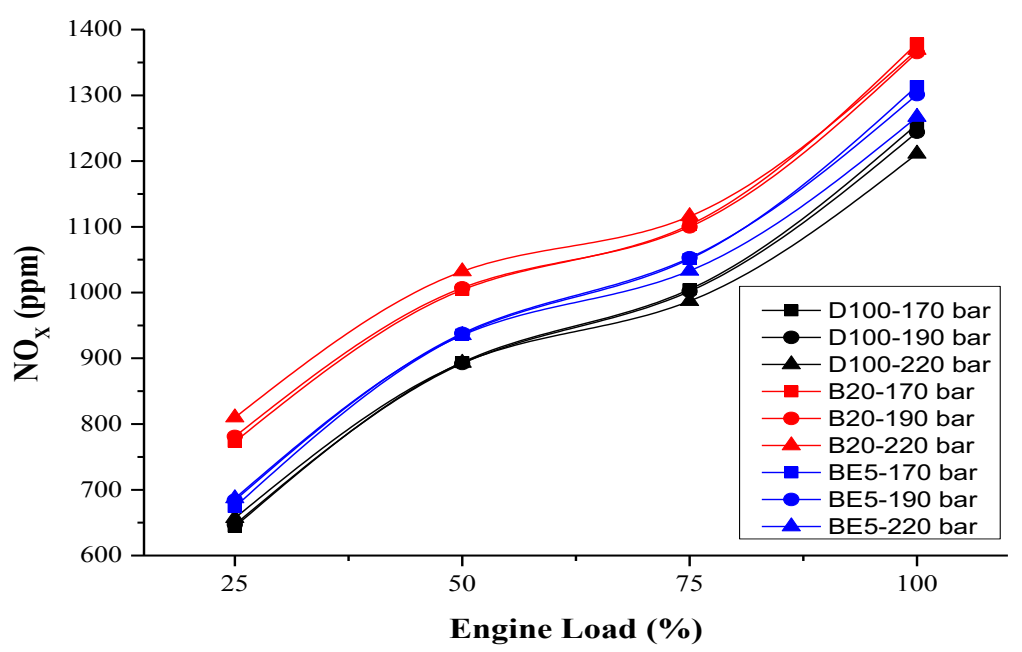

Figure 12. $\mathrm{NO}_{\mathrm{x}}$ emissions at various engine loads and injection pressures

\section{Smoke Opacity}

The smoke especially has been produced in fuel-rich areas of the combustion chamber (Barabás et al., 2010). In Figure 13, imaged the smoke opacity emissions at various engine loads and injection pressures, the curve of smoke opacity has an increasing slope with engine torque such that it reaches its maximum at $100 \%$ engine load conditions. As it can be seen, B20 produces less (by average 20.5\%) smoke opacity than diesel, when BE5 produces lesser (approximately by $30 \%$ ) smoke opacity than B20. Studies, deals with the variation of smoke opacity of diesel fuel and diesel-biodiesel-ethanol triple fuel blends versus engine load, emphasizes similar results with ours i.e.: (PrabakaranUdhoji, 2016). As stated in these studies, the presence of ethanol brings smoke opacity under control. Although, rise in injection pressure causes an increase in smoke opacity values by $6.4 \%$ for BE5 due to its high flame speed (Qi et al., 2017), its smoke opacity values in high injection pressure are lower approximately by $45 \%$ than that of diesel.

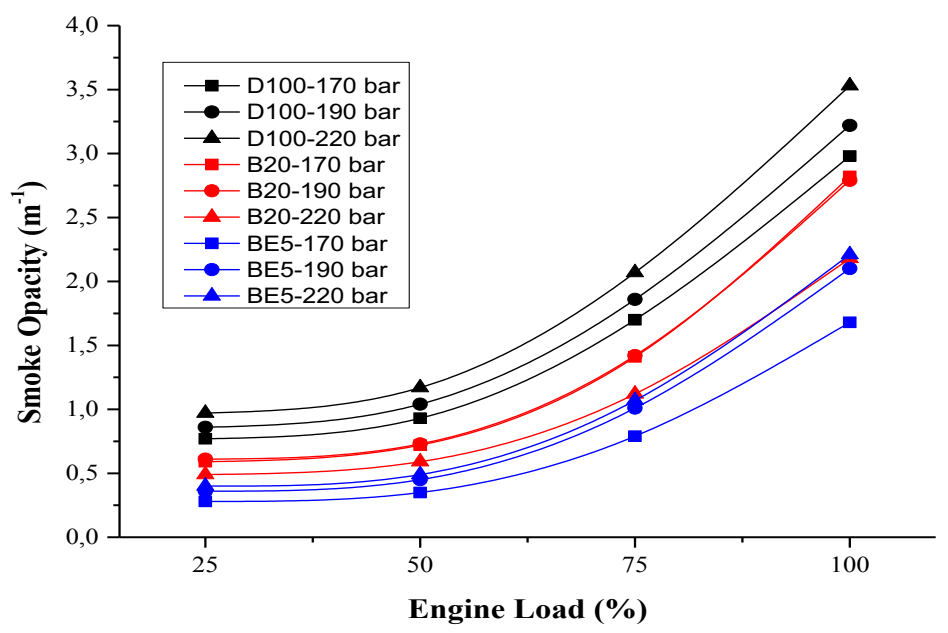

Figure 13. Smoke opacity at various engine loads and injection pressures 


\section{CONCLUSION}

This study deals with the effect of biodiesel and bioethanol content of B20 and BE5 fuel blends respectively. The effects of these fuels on engine performance exhaust emissions and combustion parameters for different test conditions are investigated and presented below.

- $\quad$ BSFC values of BE5 fuel was improved by average $9 \%$ with rise in injection pressure. Thus, a decrease by $3.2 \%$ was obtained according to results of diesel fuel at injection pressure of 190 bar.

- The rise in injection pressure caused higher BTE values by approximately $10 \%$ with BE5 for 190 bar injection pressure. Besides, bioethanol addition increased BTE by $9 \%$ at high injection pressure compared to that of diesel fuel at 190 bar.

- It was observed that bioethanol shortened combustion duration and it lengthened ignition delay due to the lower cetane number of it. Although, the highest cylinder pressure was obtained with BE5 at low engine speed, it was obtained with B20 at high engine speed. Maximum cylinder pressure increased at low engine speed, and it decreased at high engine speed for all test fuels.

- BE5 fuel has the highest HRR value at all test conditions (especially at high injection pressure) due to its oxygen contents. This case affected negatively combustion efficiency for flame is quickly extinguished.

- The oxygen content in both biodiesel and bioethanol decreased CO, HC and smoke opacity values. Especially, high exhaust gas temperature of $\mathrm{B} 20$ caused an increase in $\mathrm{NO}_{\mathrm{x}}$ emission. It was observed that in generally, BE5 provided release of lower harmful exhaust emissions. $\mathrm{CO}_{2}$ emissions of it at high injection pressure were quite low (approximately 12\%) compared to that of D100 at 190 bar.

As result, high density and viscosity values of biodiesel were decreased slightly, and cold flow properties were improved owing to bioethanol addition. But, its low cetane number and LHV caused worse engine performance and combustion characteristics. These negative effects resolved significantly thanks to increase of injection pressure. The better performance and exhaust emission values obtained with use of BE5 at high injection pressure.

\section{ACKNOWLEDGMENT}

This study was supported by the grants from Scientific Research Projects Coordination Unit of Selcuk University (Projects No: 13401032) and Automotive Application and Research Center of Selcuk University.

\section{REFERENCES}

Aktaş, A., \& Şahin, Ö. 2009. Dizel/biyodizel karışımı ile çalışan bir motorun performans ve emisyonlarını iyileştirmek için hidrojen kullanılması. Uludağ University Journal of The Faculty of Engineering 14(1).

Barabás, I., Todoruţ, A., \& Băldean, D. 2010. Performance and emission characteristics of an CI engine fueled with diesel-biodiesel-bioethanol blends. Fuel 89(12): 3827-3832.

Can, Ö. 2014. Combustion characteristics, performance and exhaust emissions of a diesel engine fueled with a waste cooking oil biodiesel mixture. Energy Conversion and Management 87: 676-686.

Can, Ö., Öztürk, E., Solmaz, H., Aksoy, F., Çinar, C., \& Yücesu, H. S. 2016. Combined effects of soybean biodiesel fuel addition and EGR application on the combustion and exhaust emissions in a diesel engine. Applied Thermal Engineering 95: 115-124.

Çelik, M., Örs, İ., Bayindirli, C., \& Demiralp, M. 2017. Experimental investigation of impact of addition of bioethanol in different biodiesels, on performance, combustion and emission characteristics. Journal of Mechanical Science and Technology 31(11): 5581-5592. 
Du, W., Zhang, Q., Zhang, Z., Lou, J., \& Bao, W. 2018. Effects of injection pressure on ignition and combustion characteristics of impinging diesel spray. Applied Energy 226: 1163-1168.

Emiroğlu, A. O., \& Şen, M. 2018. Combustion, performance and exhaust emission characterizations of a diesel engine operating with a ternary blend (alcohol-biodiesel-diesel fuel). Applied Thermal Engineering 133: 371380 .

Hulwan, D. B., \& Joshi, S. V. 2011. Performance, emission and combustion characteristic of a multicylinder DI diesel engine running on diesel-ethanol-biodiesel blends of high ethanol content. Applied Energy 88(12): 5042-5055.

Ilkılıç, C., Aydın, S., Behcet, R., \& Aydin, H. 2011. Biodiesel from safflower oil and its application in a diesel engine. Fuel processing technology 92(3): 356-362.

Işık, M. Z., \& Aydın, H. 2016. Analysis of ethanol RCCI application with safflower biodiesel blends in a high load diesel power generator. Fuel 184: 248-260.

Jamrozik, A., Tutak, W., Pyrc, M., \& Sobiepański, M. 2017. Effect of diesel/biodiesel/ethanol blend on combustion, performance and emissions characteristics on a direct injection diesel engine. Thermal Science 21(1B): 591-604.

Kannan, D., Pachamuthu, S., Nurun Nabi, M., Hustad, J. E., \& Løvås, T. 2012. Theoretical and experimental investigation of diesel engine performance, combustion and emissions analysis fuelled with the blends of ethanol, diesel and jatropha methyl ester. Energy Conversion and Management 53(1): 322-331.

Labeckas, G., Slavinskas, S., \& Mažeika, M. 2014. The effect of ethanol-diesel-biodiesel blends on combustion, performance and emissions of a direct injection diesel engine. Energy Conversion and Management 79: 698720.

Lakshminarayanan, P. A., \& Aghav, Y. V. (2010). Ignition Delay in a Diesel Engine. In P. A. Lakshminarayanan \& Y. V. Aghav (Eds.), Modelling Diesel Combustion (pp. 59-78). Dordrecht: Springer Netherlands.

Lei, J., Shen, L., Bi, Y., \& Chen, H. 2012. A novel emulsifier for ethanol-diesel blends and its effect on performance and emissions of diesel engine. Fuel 93: 305-311.

Li, D.-g., Zhen, H., Xingcai, L., Wu-gao, Z., \& Jian-guang, Y. 2005. Physico-chemical properties of ethanoldiesel blend fuel and its effect on performance and emissions of diesel engines. Renewable Energy 30(6): 967-976.

Mofijur, M., Rasul, M. G., Hyde, J., Azad, A. K., Mamat, R., \& Bhuiya, M. M. K. 2016. Role of biofuel and their binary (diesel-biodiesel) and ternary (ethanol-biodiesel-diesel) blends on internal combustion engines emission reduction. Renewable and Sustainable Energy Reviews 53: 265-278.

Noorollahi, Y., Azadbakht, M., \& Ghobadian, B. 2018. The effect of different diesterol (diesel-biodieselethanol) blends on small air-cooled diesel engine performance and its exhaust gases. Energy 142: 196-200.

Park, S. H., Cha, J., \& Lee, C. S. 2012. Impact of biodiesel in bioethanol blended diesel on the engine performance and emissions characteristics in compression ignition engine. Applied Energy 99: 334-343.

Paul, A., Panua, R., \& Debroy, D. 2017. An experimental study of combustion, performance, exergy and emission characteristics of a CI engine fueled by Diesel-ethanol-biodiesel blends. Energy 141: 839-852.

Prabakaran, B., \& Udhoji, A. 2016. Experimental investigation into effects of addition of zinc oxide on performance, combustion and emission characteristics of diesel-biodiesel-ethanol blends in CI engine. Alexandria Engineering Journal 55(4): 3355-3362.

Pradelle, F., Leal Braga, S., Fonseca de Aguiar Martins, A. R., Turkovics, F., \& Nohra Chaar Pradelle, R. 2019. Performance and combustion characteristics of a compression ignition engine running on dieselbiodiesel-ethanol (DBE) blends - Potential as diesel fuel substitute on an Euro III engine. Renewable Energy 136: $586-598$. 
Qi, D., Yang, K., Zhang, D., \& Chen, B. 2017. Combustion and emission characteristics of diesel-tung oilethanol blended fuels used in a CRDI diesel engine with different injection strategies. Applied Thermal Engineering 111: 927-935.

Rakopoulos, D. C., Rakopoulos, C. D., \& Giakoumis, E. G. 2015. Impact of properties of vegetable oil, biodiesel, ethanol and n-butanol on the combustion and emissions of turbocharged HDDI diesel engine operating under steady and transient conditions. Fuel 156: 1-19.

Sastry, G. R. K., Deb, M., \& Panda, J. K. 2015. Effect of Fuel Injection Pressure, Isobutanol and Ethanol Addition on Performance of Diesel-biodiesel Fuelled D.I. Diesel Engine. Energy Procedia 66: 81-84.

Sayin Kul, B., \& Kahraman, A. 2016. Energy and Exergy Analyses of a Diesel Engine Fuelled with BiodieselDiesel Blends Containing 5\% Bioethanol. Entropy 18(11).

Shehata, M., Attia, A. M., \& Razek, S. A. 2015. Corn and soybean biodiesel blends as alternative fuels for diesel engine at different injection pressures. Fuel 161: 49-58.

Tse, H., Leung, C. W., \& Cheung, C. S. 2015. Investigation on the combustion characteristics and particulate emissions from a diesel engine fueled with diesel-biodiesel-ethanol blends. Energy 83: 343-350.

Valente, O. S., Pasa, V. M. D., Belchior, C. R. P., \& Sodré, J. R. 2012. Exhaust emissions from a diesel power generator fuelled by waste cooking oil biodiesel. Science of the total environment 431: 57-61.

Van Gerpen, J. H., Peterson, C. L., \& Goering, C. E. (2007). Biodiesel: An alternative fuel for compression ignition engines: American Society of Agricultural and Biological Engineers.

Venu, H., \& Madhavan, V. 2017. Influence of diethyl ether (DEE) addition in ethanol-biodiesel-diesel (EBD) and methanol-biodiesel-diesel (MBD) blends in a diesel engine. Fuel 189: 377-390.

Yildizhan, Ş., Uludamar, E., Çalık, A., Dede, G., \& Özcanlı, M. 2017. Fuel properties, performance and emission characterization of waste cooking oil (WCO) in a variable compression ratio (VCR) diesel engine. European Mechanical Science 1(2): 56-62.

Yilmaz, N., Vigil, F. M., Burl Donaldson, A., \& Darabseh, T. 2014. Investigation of CI engine emissions in biodiesel-ethanol-diesel blends as a function of ethanol concentration. Fuel 115: 790-793. 